\title{
Geographic information system (GIS) based soil loss estimation using RUSLE model for soil and water conservation planning in anka_shashara watershed, southern Ethiopia
}

\begin{abstract}
Water induced soil erosion has been continued to threaten the land resources in sub humid northwestern highlands of Ethiopia. Human-induced land cover (LC) changes due to improper land management practices are contributing factors in deteriorating soil quality. Soil and water conservation measures have been implemented without site-specific scientifically quantified soil erosion data and priority bases in this regard; this study was conducted with a view to quantifying soil erosion in Anka-Shashara watershed. To do this, we have opted to use the RUSLE model based on geographic information systems. By collecting data on rainfall, soils, vegetation, slopes and conservation practices separately as a layer and determining the pixel values for each of these factors, a quantified assessment of erosion in the basin is obtained. The result reveals that the mean annual soil loss $(15.22 \mathrm{t} / \mathrm{ha} / \mathrm{yr})$ of the most parts of study area falls in tolerable levels and almost $66 \%$ (1594 ha), moderate level about $23 \%$ and $10 \%$ at high level of watershed. The soil loss of watershed is classified in to four main classes. None to Slight rates of soil erosion (0-10t/ ha) is cover the almost $66 \%$ of watershed moderate about $23 \%$ and high about $10 \%$ of erosion rate as seen from the erosion rate distribution map. The upstream of catchment needs management and protection of those existing resources and the fundamental attention for SWC as recommended bases. Therefore, to reduce sedimentation problem and ensue sustainability of the watershed need to special attention for implementing recommended SWC intervention at the earlier.
\end{abstract}

Volume 5 Issue I - 202 I

\author{
Meseret Bekele \\ Department of Water Resource Engineering and Management, \\ Hawassa University, Ethiopia
}

\begin{abstract}
Correspondence: Meseret Bekele, Department of Water Resource Engineering and Management, Hawassa University, Ethiopia, Email meseretbekelet@gmail.com
\end{abstract}

Received: December 23, 2020 | Published: January 20, 2021

Keywords: GIS, RUSLE, soil loss, Anka-shashara

\section{Introduction}

In Ethiopia, biophysical and socioeconomic constraints, and suboptimal utilization and management of soil and water resources have resulted in progressive reduction of land productivity. ${ }^{1}$ Productive land and adequate water availability is crucial for sustainable development and increased food production those countries base their livelihood on agriculture. The availability of this vital resource is not guaranteed for large sections of the world's population. Over $40 \%$ of the extra food required to meet the growing food demands by 2025 will have to come from intensified rain fed farming in sub-Saharan Africa region. In contrast almost quarter of Sub-Saharan Africa (SSA) population lives in water and fertile soil stressed areas. ${ }^{2}$ As in the other parts of the world, major land cover changes have also been occurred in Ethiopia. For instance, a significant increase in cultivated land at the expense of forest land was found to have occurred at local and regional levels. Information on local level land use dynamics is essential for designing sound environmental policies and management. It provides a base line data required for proper understanding of how land was used in the past and the type of changes to be detected in the future. ${ }^{3}$ Humaninduced land cover (LC) changes due to improper land management practices are contributing factors in deteriorating soil quality. The extent of fertile land available for agriculture is decreasing due to land degradation. Land degradation is caused by deforestation and inappropriate use and management of the natural resources (soil and water). It leads to both non sustainable agricultural production and increased risks of catastrophic flooding, sedimentation, landslides. ${ }^{4}$ Rapid population growth, existing agricultural production system; cultivation on steep slopes, clearing of vegetation and overgrazing, low inherent land productivity, lack of capital, inadequate support services and poverty are the main factors that accelerate soil erosion. ${ }^{5}$

The impact of soil erosion has results both in on-site nutrient loss and off-site sedimentation of water resources in arid and semi-arid areas like Ethiopia. Farmers are highly dependent on intrinsic land properties and unable to improve soil fertility through application of purchased inputs. ${ }^{6}$ Studies made in different parts of Ethiopia reported that annual soil loss show spatial and temporal variations. Based on the modeling, Soil Conservation Research Project (SCRP) estimated that about 1.5 billion tons of soil is eroded every year from the Ethiopian highlands. ${ }^{7}$ In the past, $\mathrm{FAO}^{8}$ and $\mathrm{Hurni}^{9}$ reported annual soil loss from Ethiopian highlands to be 200-300 tons $\mathrm{ha}^{-1} \mathrm{yr}^{-1}$. Similarly, Hurni et al. ${ }^{9}$ estimated that soil loss due to erosion of cultivated fields in Ethiopia amounts to about 42 tons $\mathrm{ha}^{-1} \mathrm{yr}^{-1}$. The average crop yield from a piece of land in Ethiopia is very low mainly due to soil fertility decline associated with removal of topsoil by erosion. ${ }^{10}$ As a result of soil erosion, Ethiopia losses USD 1 billion $\mathrm{yr}^{-111}$ and is still affecting $50 \%$ of the agricultural area and $88 \%$ of the total population of the country. ${ }^{12}$ Erosion could also generate deposition of soil materials in the reservoirs, irrigation schemes and waterways downstream. ${ }^{13}$ It is true that the inherent characteristics of the soil greatly affect 
agricultural productivity. In increasing agricultural yield, it becomes essential to understand the properties of soils. It is only when we have adequate knowledge on soils that we can manage according to their potentials and limits and thereby maximize agricultural (crop) production to the allowable potential limits and conserve soils for future generation. ${ }^{14}$

Accordingly, offering adequate soil and water to the users, in the right quantities, at the right places and at the right time, by applying environmentally sound techniques and procedures is required for effective management of soil and water resource. Proper management of on-site effect of soil erosion reduces the risks and negative impacts of downstream water resources due to water erosion. Tackling the onsite effects of soil erosion requires an understanding of the rates of erosion processes as well as identification of the major controlling factors that aggravate or reverse the processes. So, this particular study was distinguished the potential causes and the associated reasons behind the respective causes for soil erosion and preparing watershed management plan. Integrated watershed management plan is the process of evaluating, planning, restoring, and organizing land and other resource use within a watershed to provide desired goods and services while maintaining a sustainable ecosystem. This process provides a chance for agencies and stakeholders to balance diverse goals and uses for environmental resources, and to consider how their cumulative actions may affect long-term sustainability of natural resources. Therefore, identifying land use changes behind and developing appropriate measures to minimize the ecological effects have great deal of importance for integrated watershed management. This study was therefore aimed at analyzing the rate of soil erosion due to land use/cover and recommend possible watershed management plan which would be practical and acceptable both socially, economically and politically in the Anka-shashara watershed, southern Ethiopia. Specific objectives are identification of soil degradation through modeling in Anka-shashara watershed, classification and prioritization of critical erosion prone areas for conservation planning and recommend possible watershed development and management plan in the sub-watershed.

\section{Materials and methods}

\section{General description of watershed area}

The study area were found in southern Ethiopia, Wolaita Zone, bounds of Ankasha Shara watershed from 33079'95" to 34 $81^{\circ}$ ' $41^{\prime \prime}$ E, and $75^{\circ} 55^{\prime} 14^{\prime \prime}$ to $76^{0} 33^{\prime} 84^{\prime \prime}$ N UTM coordinates. Its coverage area is about 2405 ha with an altitude of $1450 \mathrm{~m}$ to 2286 masl. The watershed is located in two Woredas of Damot Woyde and Duguna Fango which including ten rural Kebeles. The farming system in the watershed and study area is typically mixed farming system, which is characterized by cultivation of crops (annual and perennial) and livestock raring. Crop production in the study area is practiced largely in a traditional way which predominantly depends on the rainfall moisture sources with a bimodal pattern enabling to perform two crop production seasons. The major crops in the watershed include teff, maize, Haricot bean, wheat, horse bean, pea and potato. The livestock include cattle, sheep, goats and donkey. The land use system experiences a double rain season, both of which are adequate for crop production, and thus for tree establishment. Total population estimated in the watershed are 53, 200 (27,132 are females). Generally, the area has a great deal specialty in the production of perennial, root and cereal crops. According to the bureau report, there is some extent of traditional irrigation system practiced by some farm households for the production of major crops comprising potato, onion, beet root and cabbage. The livestock sector is an important and integral component in the mixed farming system. The major livestock types in the study area are cattle, sheep, goat, mules, horses, bee, and poultry. The livestock sector provides: draught power for cultivation, threshing and transportation, food and income to households, producing export commodities such as hides and skins, live animals and to earn foreign exchange to the country; manure to improve soil fertility; sources of fuel; and increase economic stability to farm households. Even though, there is good practice of stall feeding of sheep and cattle for fattening purpose, which can also have promoted as a good livestock management practice, there is free grazing in the watershed. Therefore, there is an entry point to abandon the interference of livestock on to be implemented in watershed management practices (Figure 1).
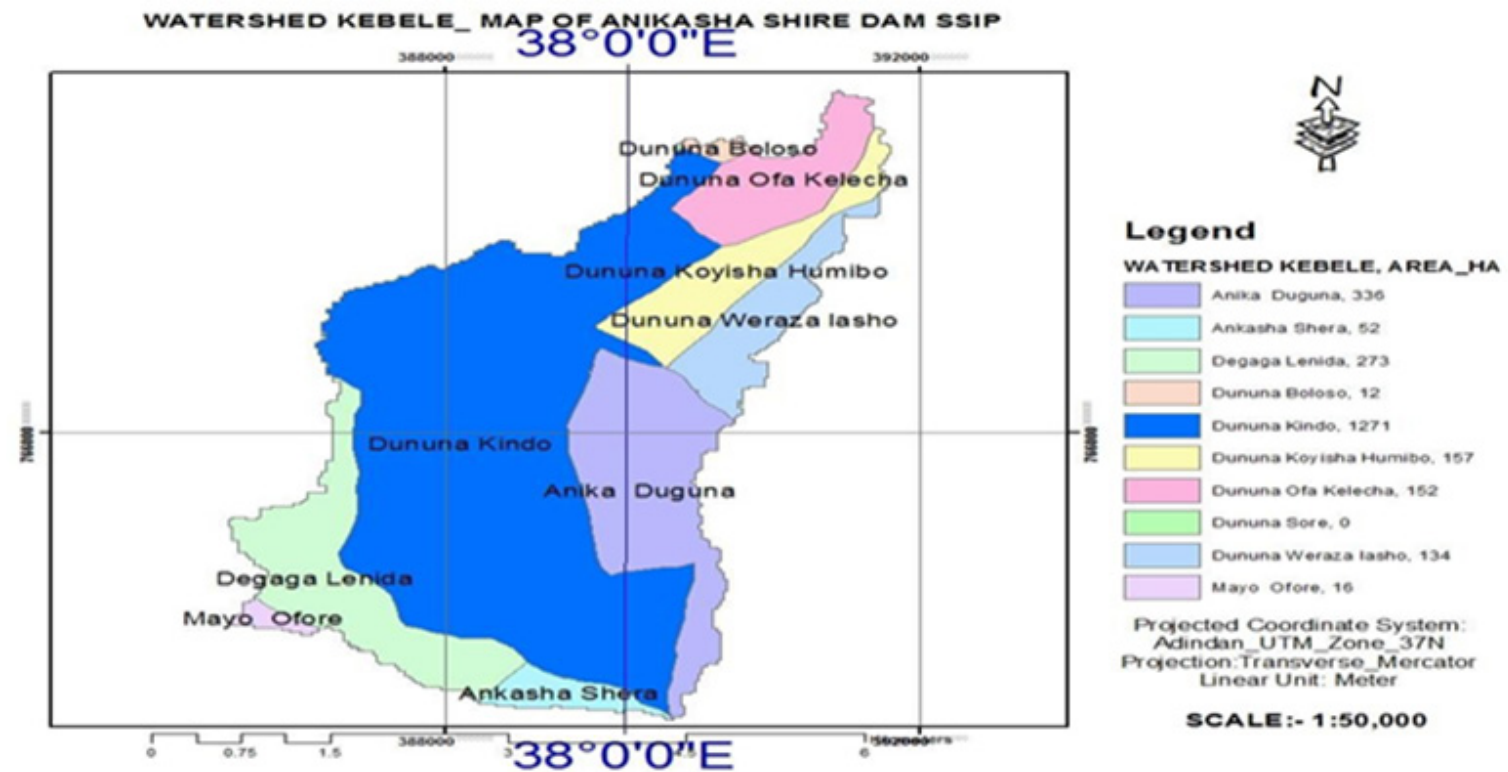

Figure I Location map of Anka_shashara watershed. 


\section{Data collection methods}

Various data collection approaches and methods have been used for the watershed management study; to enable looking at different levels in the system features and resources of the watershed in relation to its dynamics in diversity, coverage and constraints. The tools used in the data collection (primary and secondary data) were from SNNPR Agriculture and natural resource and water resource bureau i,e direct observation and measurement made by the researcher, groundchecking with in-hand secondary data and conducting interviews with the local farmers. Through transect walk, data have been collected on land use/land cover types, soils vegetation types, topographic features, soil erosion and land degradation problems, types of SWC and farming practices.

\section{Discussions and secondary data collection with sectors}

In the meantime, of the field works, brief discussions were conducted with watershed Woreda and SNNPR Bureau about major problems of the watershed and their causes, adopted interventions and strategies, sustainability of the implemented SWC measures and practices, land use proclamations and possible options and potentials for future development and management of the watershed resources. These discussions have helped for cross-checking the issues raised by the community and fill the data gaps through secondary data (Figure 2).

In general, the interviews and group discussions were conducted based on the following points

I. Historical profile of the land cover types; before decade years;

II. Categories of land use and farming system of the watershed;

III. Crop production, productivity trends and related reasons;

IV. Measures practiced to improve land productivity;

V. Existence of fallowing and tree planting practice;

VI. Alternative household energy sources;

VII. Understanding on the existence of land experiences with soil erosion and

VIII. Traditional and institutional practice of soil conservation.

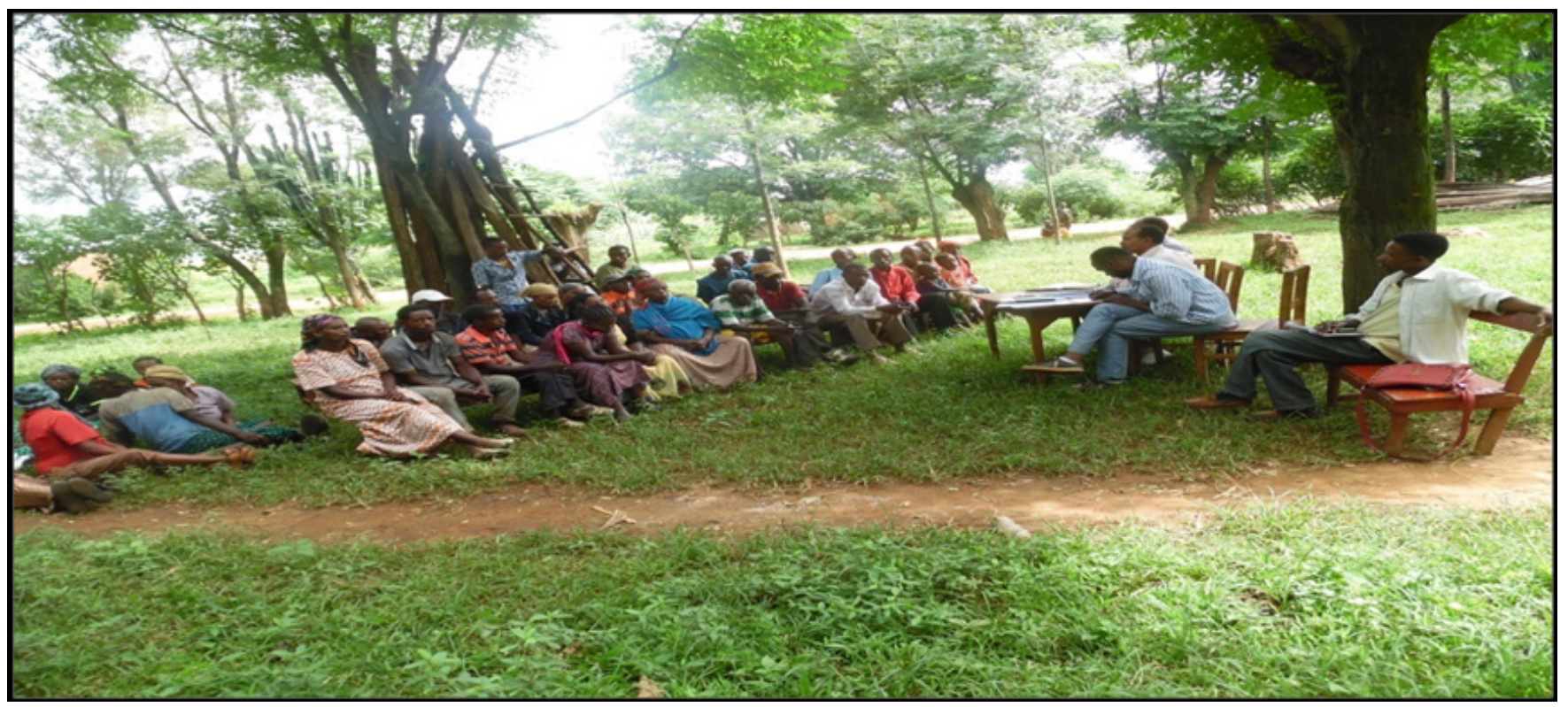

Figure 2 Discussion with community on soil erosion problem of Anka-shashara Watershed.

\section{Materials used for this study}

To undertake this study, the main materials involved were: -

I. Administrative boundaries Maps (Regional, Zonal, Woreda and watershed site);

II. Contour maps at 20 meters' intervals;

III. Land use and land cover based on Land Sat ETM of 2019;

IV. Soils, population and climatic data (rainfall, temperature, etc); and

V. The socio-economic data was collected from SNNPR Finance and economy development bureau.

The watershed boundary, which followed the natural hydrological system, and the drainage systems of the sub-watershed were generated from DEM at the spatial resolution of $30 \mathrm{~m}$. DEM data was also used to generate contour map at $30 \mathrm{~m}$ interval, altitude ranges, slope gradients, slope length, relief types, analytical hill shading, etc. In all respects, such information products had added values to further substantiate for soil erosion hazard assessment in the study area. The land use and land cover map layers were generated from the Land sat of 2019. The classification involved both supervised and unsupervised methods. The representative study areas were selected based on the pixels demonstrating regular patterns. The soil data, which mainly consisted of dominant soils, textures, depth and management constraints, were collected from secondary information and verified through intensive field survey. The meteorological data were collected from the available secondary sources of the national meteorological service agency (NMA) of Hawassa Branch office and from SNNPR water resource bureau (Table 1). The above table shows varying degree of influence of different watershed parameters on the erosion rates; runoff volumes and sediment yields at the outlet. From the results of this analysis, the watershed would yield a runoff ranging between 
few moderate to more frequent aggressive flood with a shorter peak time and higher peak flood magnitude; which also results in short lag time and with severe sediment load. Therefore, protection of the upstream catchment and strong physical \& biological SWC efforts are mandatory for sustainability of the watershed.

Table I Watershed characteristics of Anka-shashara

\begin{tabular}{|c|c|c|c|c|c|}
\hline No & Parameters & Symbol & Unit & Formula & Values \\
\hline I & Area & Ad & $\mathrm{km}^{2}$ & Measured & 24.04 \\
\hline 2 & Perimeter & $\mathrm{Pb}$ & $\mathrm{Km}$ & measured & 34 \\
\hline 3 & Basin length & Lb & $\mathrm{Km}$ & $\mathrm{Lb}=1.312 \mathrm{~A} 0.568$ & 12.31 \\
\hline 4 & Basin width & w & $\mathrm{Km}$ & $\mathrm{W}=\mathrm{A} / \mathrm{Lb}$ & 4.19 \\
\hline 5 & Total № of streams & Ns & No & Counted & 4 \\
\hline 6 & Total stream length $(L)$ & L & $\mathrm{Km}$ & Measured & 244 \\
\hline 7 & Stream density & Ds & $\mathrm{no} / \mathrm{km}^{2}$ & $\mathrm{Ns} / \mathrm{Ad}$ & 6.04 \\
\hline 8 & Main stream length & Lsm & $\mathrm{Km}$ & Measured & 16.72 \\
\hline 10 & Stream order & Os & No & Counted & 3 \\
\hline II & Drainage density & $\mathrm{Dd}$ & $\mathrm{km} / \mathrm{km}^{2}$ & $\mathrm{Dd}=\mathrm{L} / \mathrm{Ad}$ & 0.42 \\
\hline 12 & Over land flow length & Lo & M & $\mathrm{Lo}=\mathrm{I} / 2 \mathrm{Dd}$ & 0.83 \\
\hline 13 & Form factor & $\mathrm{Ff}$ & unit less & $\mathrm{Ff}=\mathrm{Ad} / \mathrm{Lb} 2$ & 0.35 \\
\hline 14 & Shape factor & B & unit less & $\mathrm{B}=\mathrm{Lm} / 2(\mathrm{Ad} / \pi) 0.5$ & 1.5 \\
\hline 15 & Elongation ratio & $\mathrm{Er}$ & unit less & $\mathrm{Er}=2(\mathrm{Ad} / \pi) 0.5 / \mathrm{Lb}$ & 0.66 \\
\hline 16 & Circularity ratio & $\mathrm{Cr}$ & unit less & $\mathrm{Cr}=4 \pi \mathrm{Ad} / \mathrm{Pb} 2$ & 0.14 \\
\hline 17 & Compactness coeff & $\mathrm{Cc}$ & Unit less & $\mathrm{Cc}=\mathrm{Pb} / 2(\pi \mathrm{Ad}) 0.5$ & 2.7 \\
\hline 18 & Texture ratio & $\mathrm{T}$ & Unit less & $\mathrm{T}=\mathrm{Ns} / \mathrm{Pb}$ & 0.08 \\
\hline
\end{tabular}

\section{Contour of Anka-shashara watershed}

Contours contain information about the relief, shape and the form of the land and the relative distribution in space of the components of the landscape of the watershed. An impression of the topography is obtained from the contours printed on this kind of map. The elevations of landmarks and reference points, such as hilltops and mountains peaks, are also printed on topographic maps. Following contour lines, it is possible to delineate watersheds within the watershed on a contour map and enables the gradient or slope between two points to be measured. Closely spaced contours on the contour map, upper part of the watershed, indicate that steeper slopes occur in those locations relative to areas that have less closely spaced contours; whereas sparse contour lines, lower part of the watershed (Figure 3).
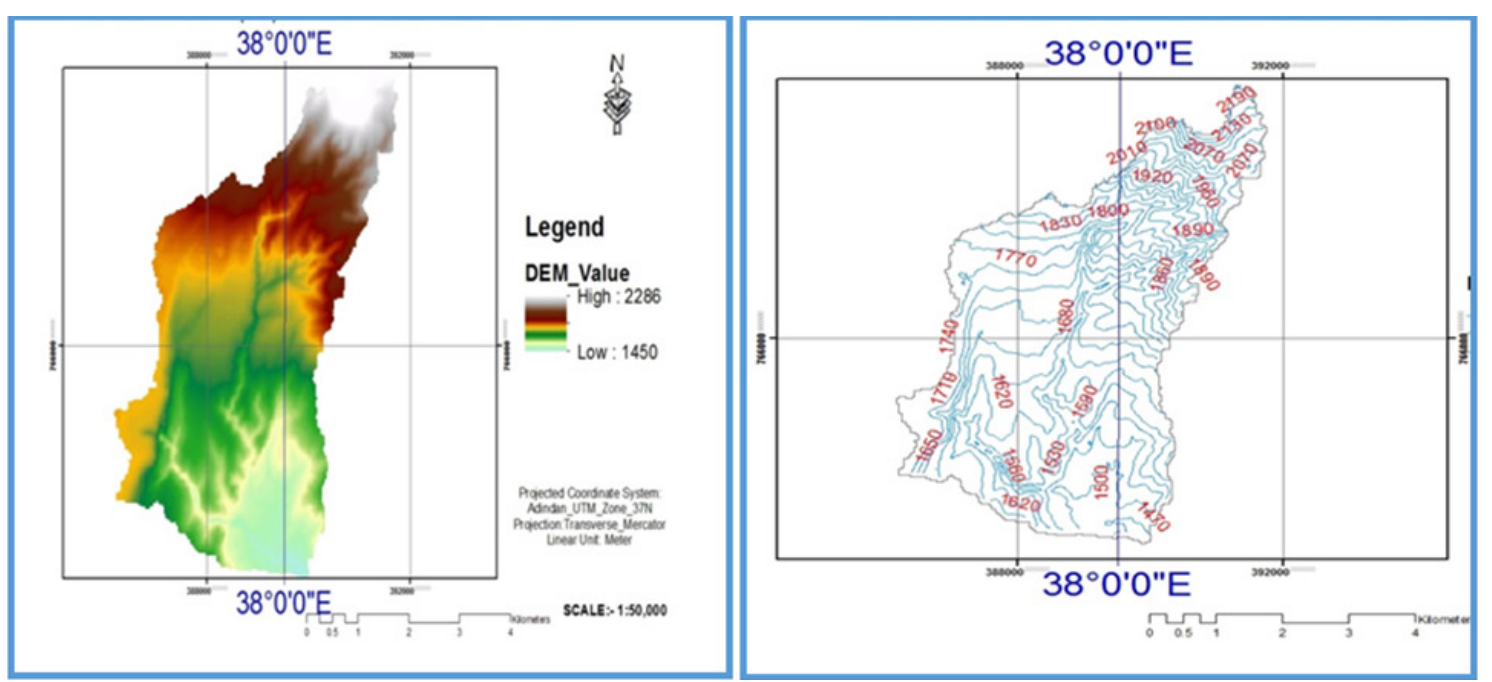

Figure 3 DEM and contour map of Anka-shashara watershed.

Citation: Bekele M. Geographic information system (GIS) based soil loss estimation using RUSLE model for soil and water conservation planning in anka_ shashara watershed, southern Ethiopia. Int J Hydro. 202I;5(I):9-2I. DOI: 10.15406/ijh.2021.05.00260 


\section{Slope of the watershed}

Based on the national guideline of Community Based Watershed Development, slope computation had also been made with six classes. The Guideline suggests the use of such classification for soil and water conservation and other land management recommendations. In most cases, slopes over 8.0 percent are generally recommended for relevant conservation interventions according to the landscape and physical human activities. According to slope classes of watersheds could be designated for various natural resources management programs under the existing conditions of the watershed (Figure 4).

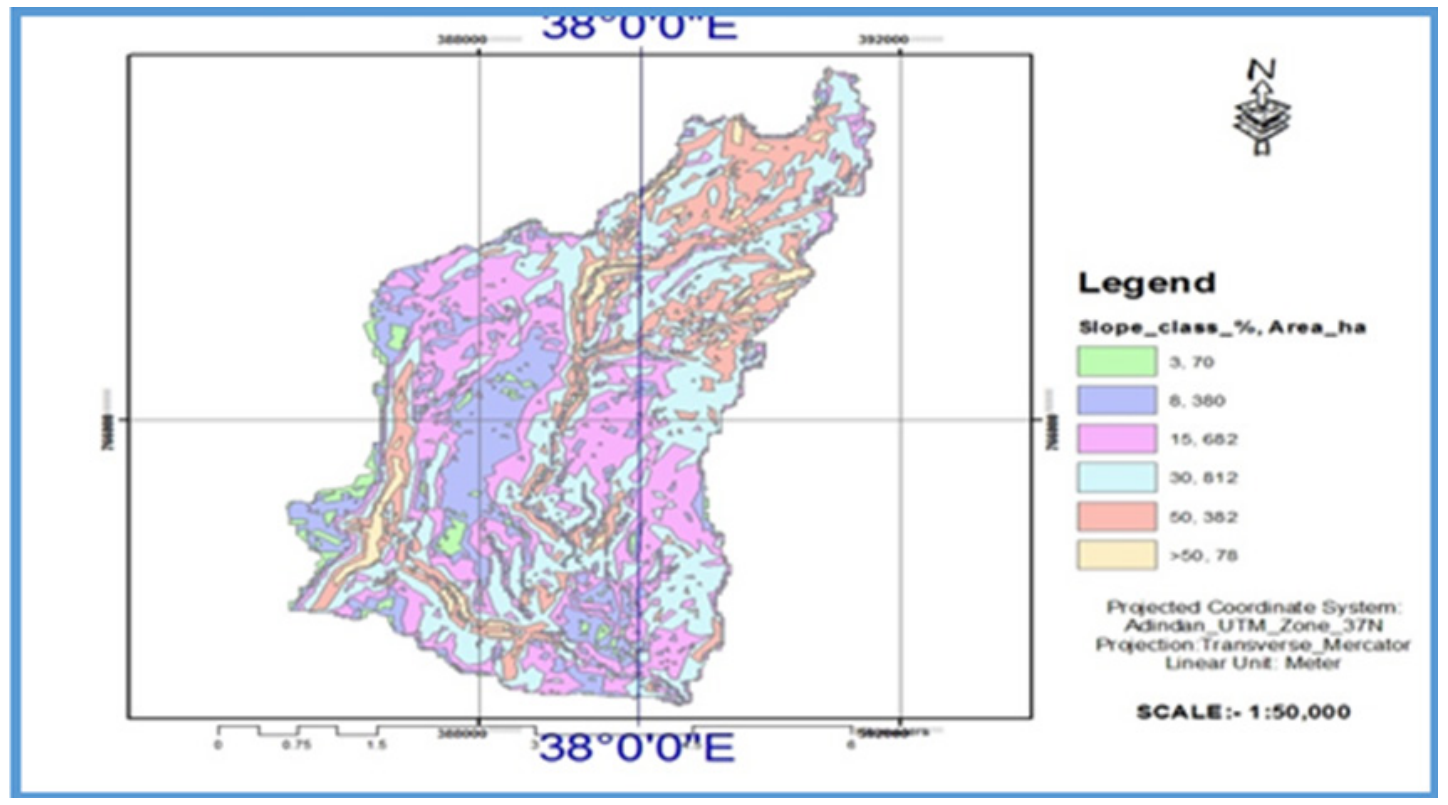

Figure 4 Slope class and their distribution in Anka-shashara watershed.

\section{Climate of the watershed}

The amount, duration and intensity of rain fall have a great effect over life on earth. Rainfall distribution is moderate and bimodal rainfall pattern where the two season merging together. The mean annual rainfall of the study area as measured at meteorological station for the period of 1995-2019 used for annual soil loss analysis. These are the closest meteorological stations to the study area (Table 2).

Table 2 Rainfall station used for this study (source: NMA hawassa branch office)

\begin{tabular}{lllll}
\hline No & Location & $\mathbf{X}$ & $\mathbf{Y}$ & $\mathbf{Z}$ \\
\hline I & Belle & 334305 & 774013 & 1200 \\
& & & & \\
3 & Merab Abaya & 367287 & 707576 & 1260 \\
4 & Whone & 378522 & 784947 & 1960 \\
\hline
\end{tabular}

\section{Soil of the watershed}

Formation of soil and its types can be varying from one geographical condition to others. For example, mountainous and hill-side terrain, due to natural weathering of rock beneath the soil and formation of soil at the surface by decaying organic and inorganic materials caused by natural process on the upper stream, whereas the accumulation silt to the lower basin is due to deposition of sediment by surface runoff, and the sediment deposition in downstream substantially larger quantities than the formation of soil in situ. Some research finding indicates that globally the time required forming soil in situ/ upstream estimates vary widely, from less than 2 years to 750 years to form $1 \mathrm{~cm}$, with most estimates lying in the range of 100-400 years or between $0.8-3$ tons/ha/year. However, it is agreed that the soil forms at much faster under farming. Also the study indicated that tillage operation probably increases the rate of top soil renewal to mount 11 tons/ha/year. Based on Ethiopian highlands reclamation study (1986), the formation of soil in the highlands of Ethiopia estimated to be 2-22 tons/ha/year. According the research finding, the formation of soil is very slow process, it takes between $200-1000$ years to structure $2.5 \mathrm{~cm}$ (1 inch) of top soil in crop land conditions, and even longer and on pasture and forest land conditions. Together with climate and terrain, soil conditions determine what agricultural production possibilities exist in a given area from a biophysical perspective. Soil erosion also depends greatly on the infiltration rate of soil. The infiltration rate again depends on the soil texture, structure, rhumus and moisture content, soil depth and surface roughness. Recommendations regarding soil conservation structures used for rehabilitation of degraded lands are based on the aforementioned soil properties. According to FAO soils classification, four the major soil types are revealed. These are Pellic vertisols, chromic luvisols, Eutric nitisols, and chromic vertisols have been identified in the watershed and the dominant soil type is Pellic vertisols $61.76 \%$ by its coverage followed by chromic luvisols $24.14 \%$ shown below with their respective erodability value (Table $3)$.This show, even though, the soil erosion was not acute problem in the watershed. The relief, soil and slope characteristics with farming activities which directly related to expansion of cultivated land on hillsides in the upper stream, requires special attention of soil conservation measures (Figure 5) \& (Table 4). 
Table 3 Soil type in Anka-shashara watershed

\begin{tabular}{lllll}
\hline No & Soil type & Area_ha & Coverage_\% & Erodablity( K) value \\
\hline 1 & Pellic vertisols & 1484 & 61.76 & 0.2 \\
2 & Chromic luvisols & 581 & 24.14 & 0.15 \\
3 & Eutric nitisols & 184 & 7.66 & 0.15 \\
4 & Chromic vertisols & 156 & 6.45 & 0.2 \\
& Total & 2405 & 100 & \\
\hline
\end{tabular}

Source: GIS 10.3 Computed data, February, 2020

Table 4 Land use/cover area of Anka-shashara watershed

\begin{tabular}{lllll}
\hline No & Types of land cover & Area & Coverage \% & C_Value \\
\hline I & Perennial Crop & 357 & 14.86 & 0.15 \\
2 & Annual Crop & 566 & 23.55 & 0.23 \\
3 & Closed Grass & 104 & 4.33 & 0.01 \\
4 & Closed Shrub & 28 & 1.12 & 0.02 \\
5 & Sparse Forest & 1198 & 49.81 & 0.01 \\
6 & Degraded Land & 153 & 6.33 & 0.6 \\
& Total & 2405 & 100 &
\end{tabular}

Source: GIS 10.3 Computed data, February, 2020

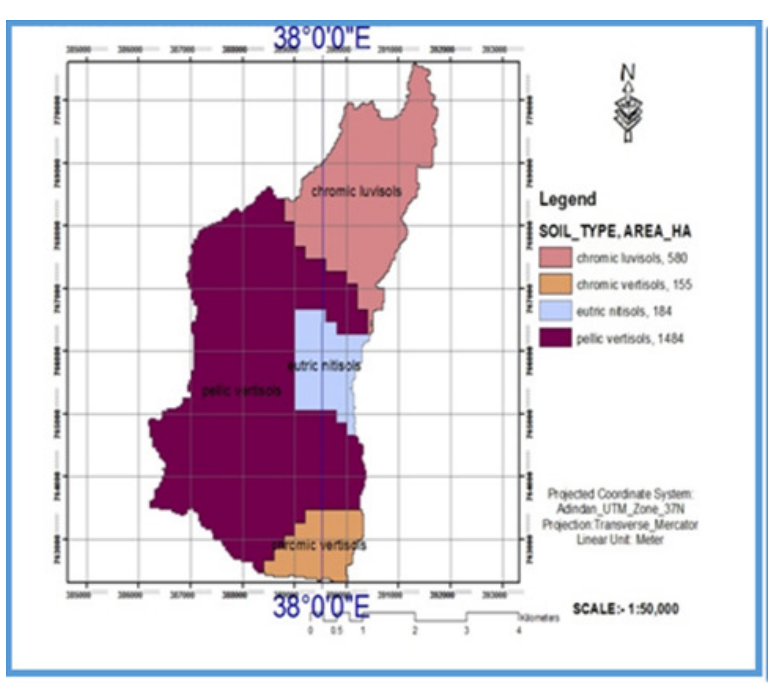

Figure 5 Soil type and Land use/cover map in Anka-shashara watershed.

\section{Result and discussion}

\section{Soil erosion rate assessment}

Erosion is the removal of soil particles from the large soil mass and transportation or dislocation of soil particles in to downstream area by running water. Sheet and rill erosions are the most prominent features to almost all cultivated lands of highland watersheds in general and this watershed in particular. Though erosion is a subtle process, the hazard is clearly seen on cultivated lands. Cultivated lands especially on the higher slopes suffer more than other land units. This can be observed by yield reduction. The quality of soil on higher slopes is more deteriorated and the color is lighter than the flat plains. Land unprotected by vegetation and cultivated steep slopes are susceptible to sheet and rill erosion. Universal soil loss equation considers the

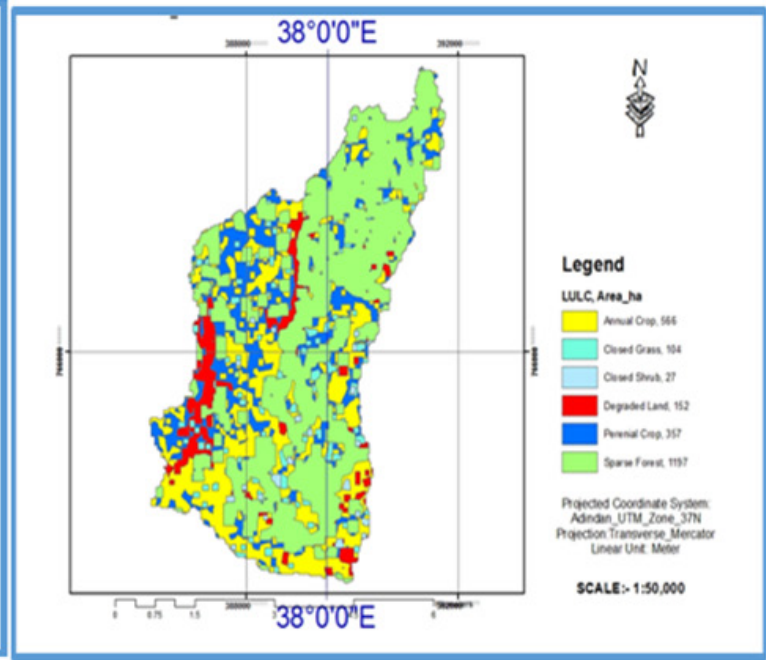

five parameters as an input and gives an annual average soil loss of the area. The equation uses rainfall erosivity, soil erodibility, slope length and gradient, soil cover, and land management practices. This mathematical equation can be represented on physical based models in the Arc GIS environment. Each variable could be overlaid to make the overall spatial analysis.

The mathematical equation of the RUSLE is given by the formula: $A=R \cdot K \cdot L S \cdot C \cdot P$

Where:

$\mathrm{A}=$ Annual soil loss in tons/ha over a period selected for R; 
$\mathrm{R}=$ Rainfall-Runoff erosivity factor in MJ. $\mathrm{mm} /$ (ha.hr);

$\mathrm{K}=$ Soil credibility factor in ( $\mathrm{t} / \mathrm{h} / \mathrm{MJ} \cdot \mathrm{mm})$;

$\mathrm{LS}=$ Topographic factor $(\mathrm{L}=\mathrm{S}$ lope length and $\mathrm{S}=$ Slope gradient factor);

$\mathrm{C}=$ Land cover and management factor; and

$\mathrm{P}=$ Treatment/conservation practice factor

\section{Rainfall erosivity factor $(\mathbf{R})$}

The soil loss is closely related to rainfall partly through the detachment power of raindrop striking the soil surface and partly through the contribution of rain to runoff (Morgan, 1994). This applies particularly to erosion by overland flow and rills for which intensity is generally considered the most important rainfall characteristics. The most suitable expression of the erosivity of rainfall is an index based on kinetic energy of the rain. Therefore, the erosivity factor $\mathrm{R}$ was calculated according to the equation given by Hurni (1985), derived from a spatial regression analysis ${ }^{15}$ for Ethiopian conditions based on the easily available mean annual rainfall $(\mathrm{P})$. It is given by a regression equation:

$$
\mathrm{R}=-8.12+0.562 * \mathrm{P}
$$

Where: $\mathrm{R}=$ Rainfall erosivity factor, and $\mathrm{P}=$ mean annual rainfall in $\mathrm{mm}$

Rainfall Erosivity (R) for study watershed is computed through long year mean annual rainfall data analysis of four meteorology stations; which is nearer distant of critical watershed center collected from National Meteorological Agency Service (Hawassa branch office). The mean annual rainfall of the critical watersheds was interpolated to generate continuous rainfall data for each grid cell by using Inverse Distance Weighted Interpolation method (IDW) in ArcGIS 10.3. The Mean rainfall and Erosivity factor of the four stations presented in table below (Table 5) \& (Figure 6).

Table $\mathbf{5}$ The mean rainfall and Erosivity $\mathrm{R}$ factor of the four stations

\begin{tabular}{llllll}
\hline No & Location & $\mathbf{X}$ & $\mathbf{Y}$ & $\mathbf{Z}$ & R-value \\
\hline I & Belle & 334305 & 774013.2 & 1200 & 570 \\
2 & Merab Abaya & 367287.2 & 707576.7 & 1260 & 391 \\
3 & Shone & 378522.6 & 784947.7 & 1960 & 714 \\
4 & Wolaita Sodo & 356341.3 & 751832.6 & 2060 & 705
\end{tabular}
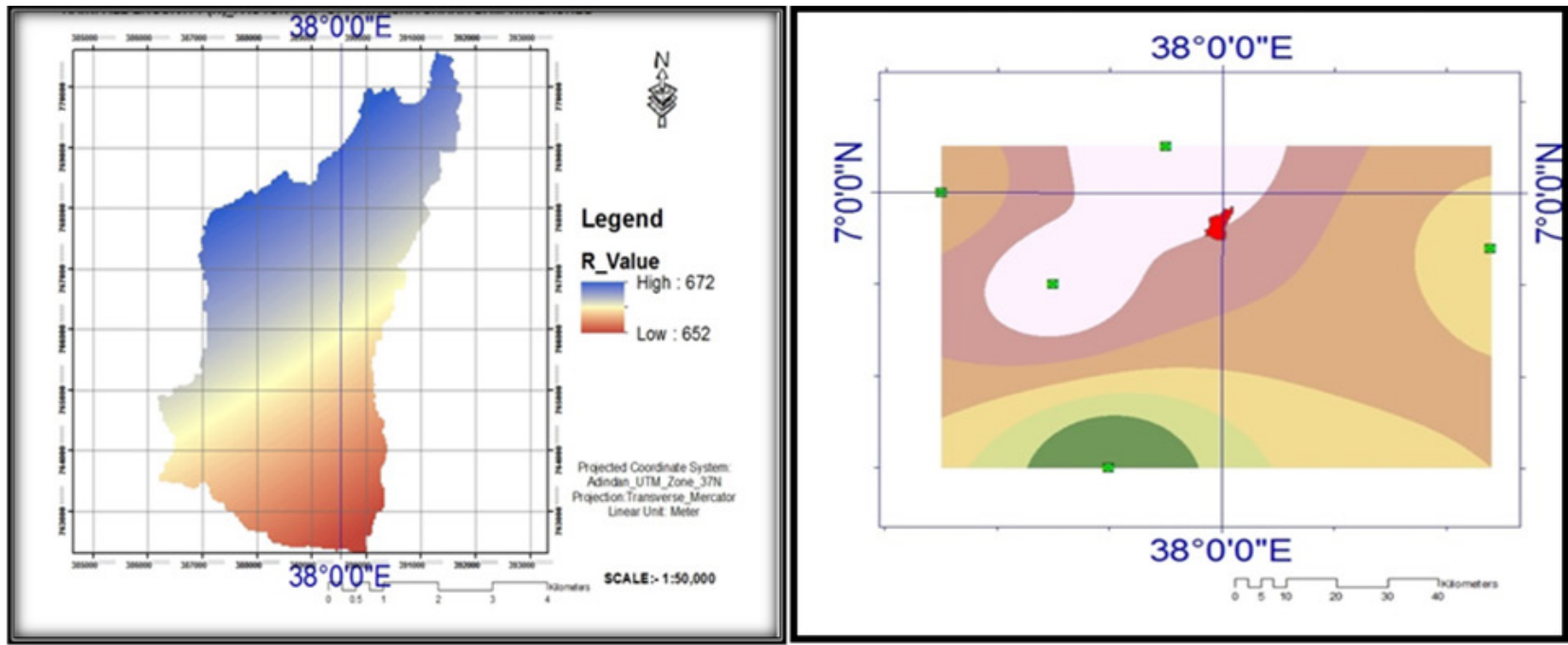

Figure 6 Erosivity factor and Inverse distance weighted interpolation of rainfall stations map of Anka-shashara watershed.

\section{Soil erodibility factor $(\mathbf{K})$}

The Soil Erodibility factor characterizes more or less the soil sensitivity towards erosion force or it is defined as mean annual rainfall soil loss per unit of $\mathrm{R}$ for a standard condition of bare soil, recently tilled up and down slope with no conservation practices and on a slope of 50 and $22 \mathrm{~m}$ length (Morgan, 1994). The value of $\mathrm{K}$ ranges from 0 to 1 . The LUPRD, supported by FAO, 1984 adopts and estimates the Erodibility value of different soil types. Therefore, the Erodibility value of the study area was adopted from FAO study as tabulated below (Figure 7).

\section{Slope length and gradient factor (LS)}

The LS characterizes the effect of topography on erosion in USLE. By using DEM with finer resolution, it is possible to calculate both slope length ' $L$ ' and slope gradient ' $S$ ' rather than having to use as has been the case in the past, resulting in far greater accuracy than in previous assessments. The slope length and gradient factors are estimated from DEM data in the ArcGIS environment. The technique described here for computing LS requires a flow accumulation grid layer and slope grid layer. The flow accumulation can be computed from the hydrological corrected DEM using Global Map per v15.0. Flow accumulation grid represents number of grid cells that are contributing for the downward flow. The cell size of the DEM represents the length of the cell. $\mathrm{L}_{\mathrm{S}}=\varphi^{*}([$ Flow. Acc] X [cell size $)]$ $/ 22.13,0.6) X \varphi^{*}((\sin [$ slope] $) \times 0.01745) / 0.09,1.3)$. Where: Cell size- represents the field slope length, and 22.13 is the length of the research field plot where the equation was derived (Figure 8).

\section{Land cover factor (C)}

The Land Cover/Land Use factor (C) represents the ratio of soil loss under a given land cover/land use to that of the base soil (Morgan, 1994). The land cover factor is also calculated for each mapping unit of a study area using the land use/cover map as an input. Each cover 
value of the study area would be synchronized with the adopted $C$ value in Ethiopian condition. The land cover factor used for this watershed analysis is the one adopted for our country's conditions as tabulated below Table 6 \& Figure 9 .

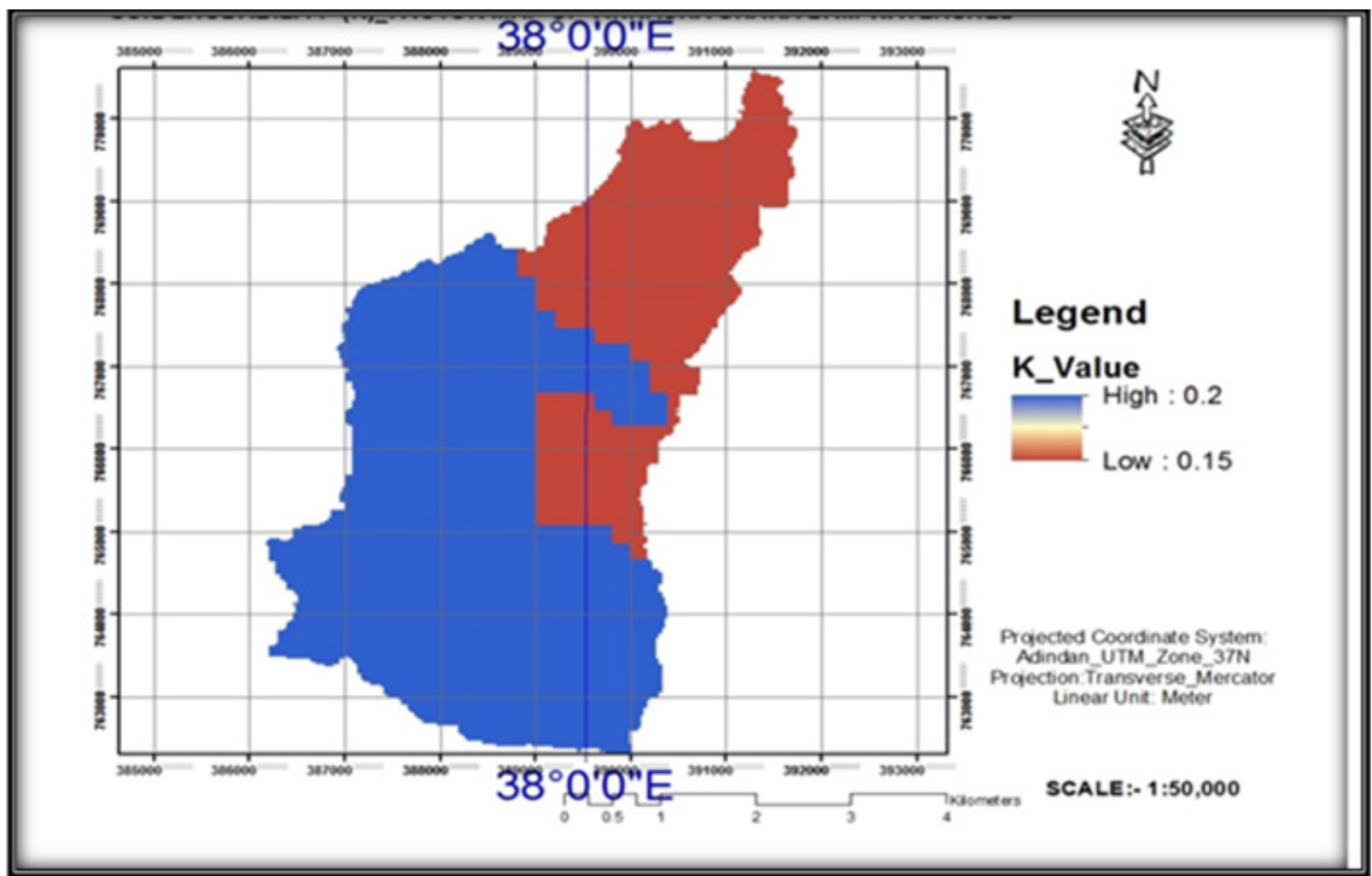

Figure 7 Soil erodibility factor map of Anka-shashara Watershed.

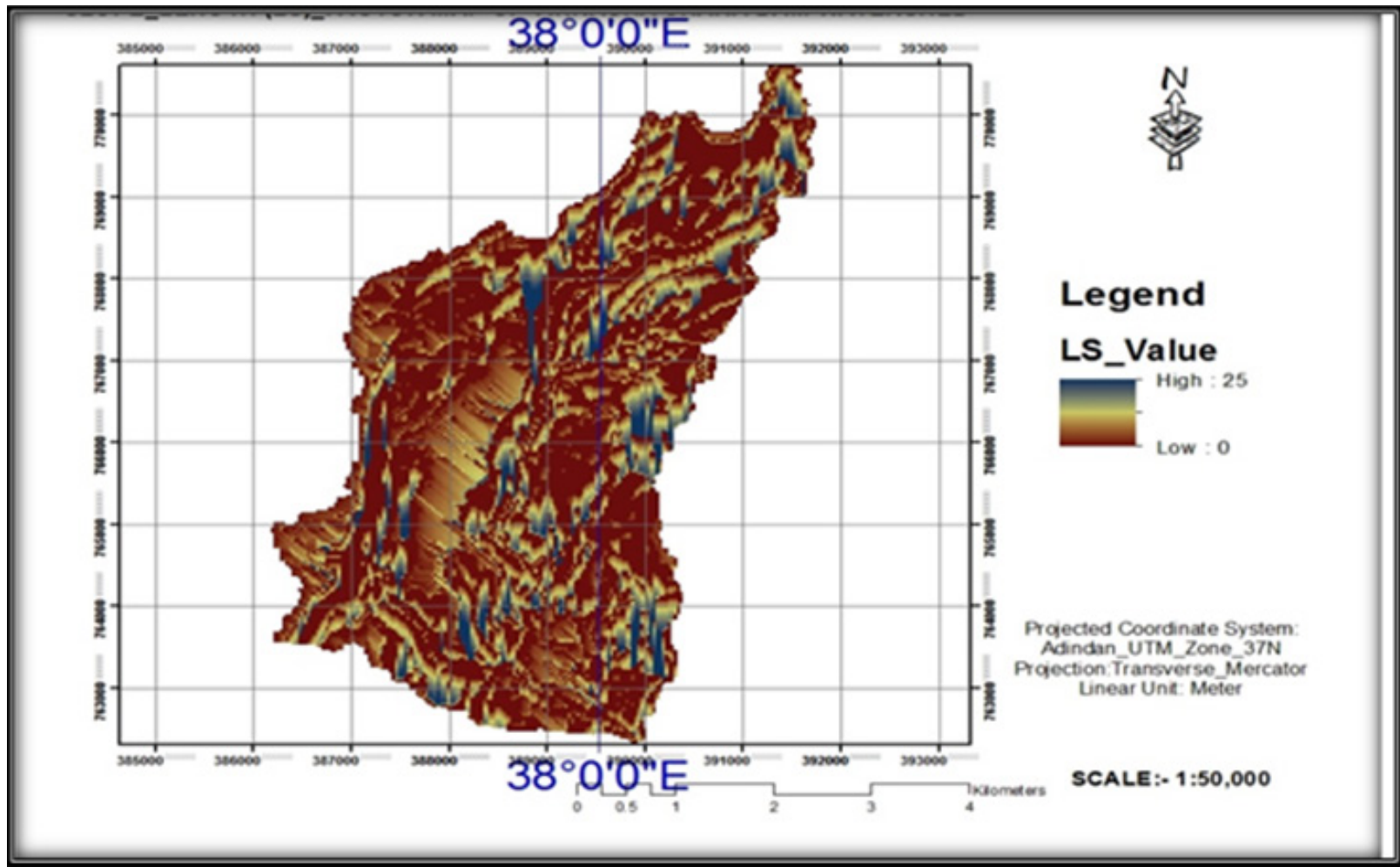

Figure 8 Slope length factor map of Anka-shashara watershed. 


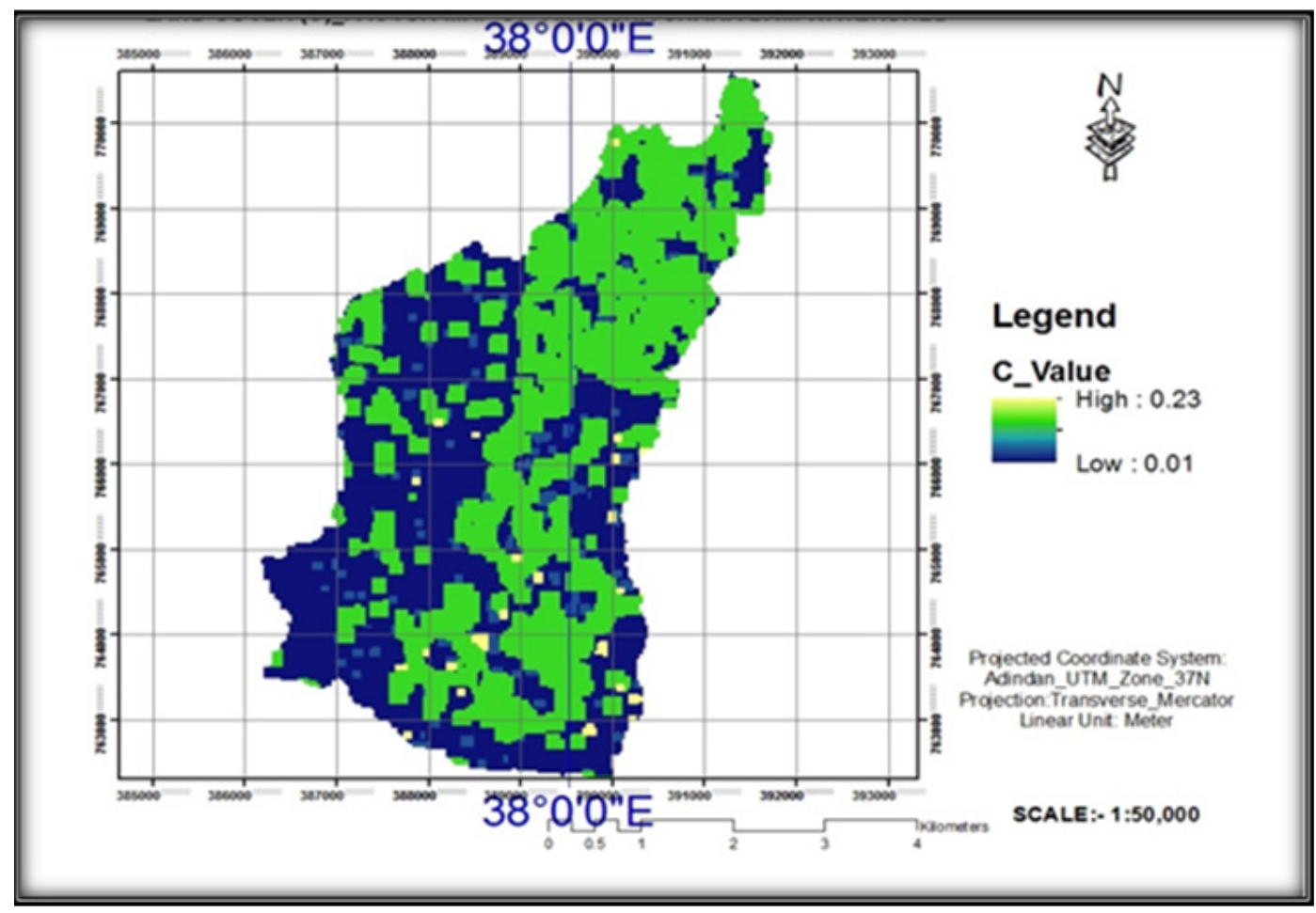

Figure 9 Land use/cover factor map of Anka-shashara watershed.

Table 6 Adopted land cover values applied to Anka-shashara Watershed

\begin{tabular}{llll}
\hline No & Land Cover/Use class & Source & C-factor \\
\hline I & Forest & Hurni, I985 & 0.01 \\
2 & Shrub land & CGIP, I996 & 0.02 \\
3 & Grass Land & CGIP, I996 & 0.01 \\
4 & Dense grass & Hurni, I985 & 0.01 \\
5 & Degraded grass & Hurni, I985 & 0.05 \\
6 & Crop land/ wooded crop land & CGIP, I996 & 0.15 \\
7 & Crop land, Teff as a main crop & Hurni, I985 & 0.25 \\
8 & Crop land, cereals, pulses & Hurni, I985 & 0.15 \\
9 & Crop land: wheat, barely & CGIP, I996 & 0.15 \\
I0 & Crop land: sorghum, maize & Hurni, I985 & 0.1 \\
II & Afro-alpine & BCEOM, I998 & 0.01 \\
I2 & Open scrub land & CGIP, I996 & 0.06 \\
I3 & Bush land & BCEOM, I998 & 0.1 \\
I4 & Bare land & BCEOM, I998 & 0.6 \\
\hline & & & \\
\hline
\end{tabular}

\section{Land management practices}

The land management practice $(\mathrm{P})$ value is also one factor that governs the soil erosion rate. The $\mathrm{P}$-value ranges from 0 to 1 depending on the soil management activities employed in the specific plot of land. These management activities are highly depending on the slope of the area. Wischmeier and Smith (1978) calculated the P-value by delineating the land in to two major land uses, agricultural land and other rural land use. Further, agricultural land sub-divided in to four and the later considered as unity bearing in mind that for this watershed upstream part has the steepest slope and thus the slope percent to assign different P-value as provided in table below. Estimation of the $\mathrm{P}$ factor, for the study area, was carried out taking in account the local conservation practices. In agricultural lands of the study area, particularly in the highland parts of the watershed, farmers plough their farmlands in all directions, i.e. both along the contour or perpendicular to the slope with ox drawn ploughs. They construct drainage ditches in crop fields along slopes to reduce runoff. The value of $P$ factor was assigned to cultivated lands based on the adopted P-value by Table $7 \&$ Figure $10{ }^{16}$ 


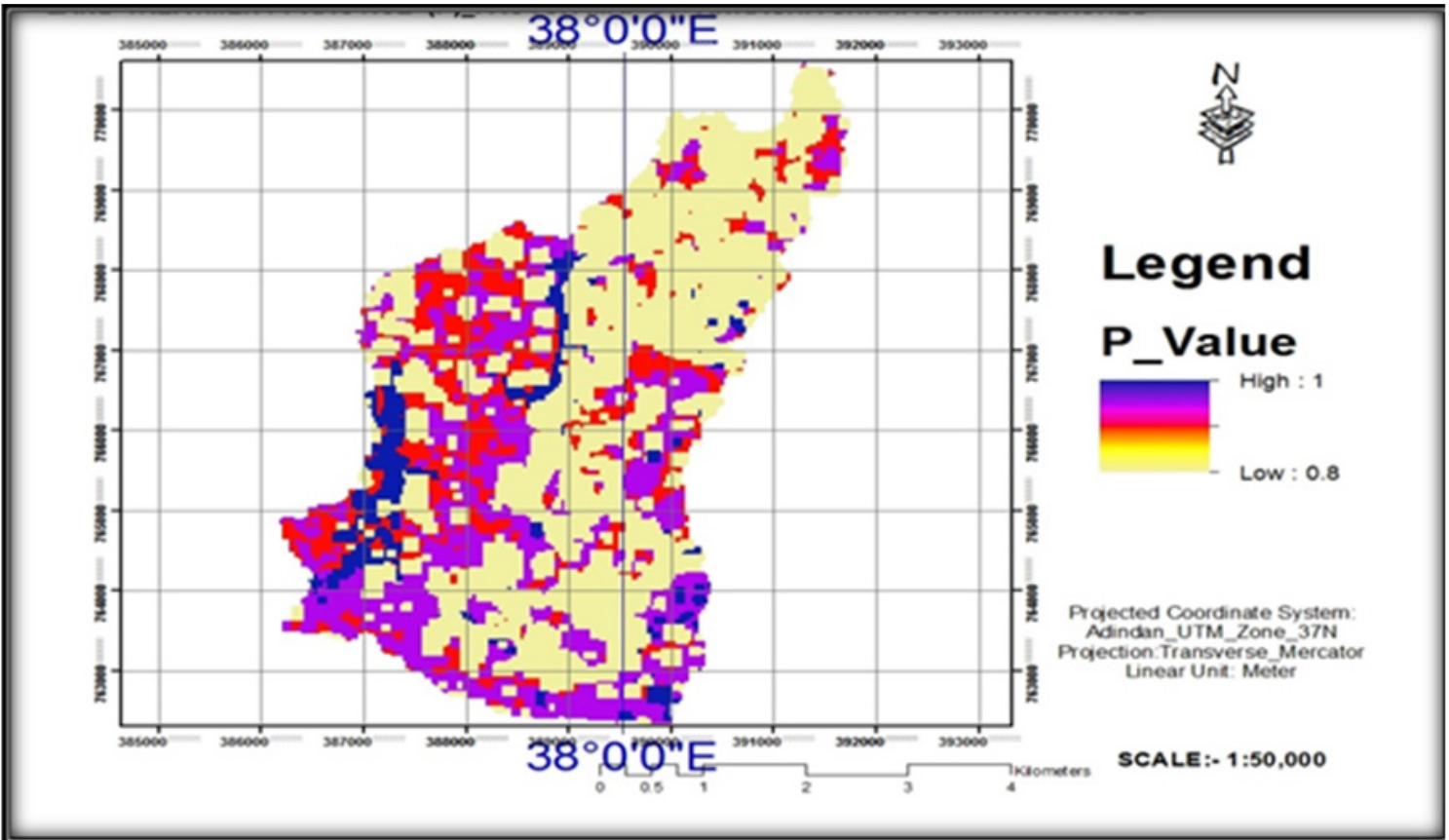

Figure 10 Land management factor map of Anka-shashara Watershed.

Table 7 P-value land management applied for watershed

\begin{tabular}{ll}
\hline Land Cover & P_Factor \\
\hline Closed Grass & 0.9 \\
Bare Soil & $\mathrm{I}$ \\
Sparse Forest & 0.8 \\
Perennial Crop & 0.9 \\
Open Shrub & 0.9 \\
Woodland & 0.9 \\
Annual Crop & 0.95 \\
\hline
\end{tabular}

\section{Annual soil loss estimation of the watershed}

Even if, erosion is a natural process, there is an option to minimize its effect but difficult to control. Therefore, it is advisable that the loss/ erosion rate should not greater than the soil formation rate. Hence, it is important to set the allowable soil loss rate; it is the rate of soil removal in which its effect not affects plant growth and yield. Soil loss tolerance refers to the maximum rate of soil loss can be tolerated without decline in economic productivity. However, the question of what level is tolerable depends on the situation of soil types and depth, its rate of formation; land use/cover, topography and so on. All the five parameters of soil loss assessment were computed using Arc GIS 10.3 geospatial database and Microsoft access database. Mean annual soil loss of Anka-shashara watershed was computed by raster calculator tool of Arc GIS10.3. According to ${ }^{17}$ annual soil loss tolerable limits in the tropical region estimated as $10 \mathrm{t} / \mathrm{ha} / \mathrm{yr}$ and estimated the soil loss tolerance level for the different agro ecological zones of Ethiopia to be the range 1-16 t/ha/yr. According to both Hurni, the mean annual soil loss $(15.22 \mathrm{t} / \mathrm{ha} / \mathrm{yr})$ of the most parts of study area falls in tolerable levels and almost 66\% (1594 ha), moderate level about 23\% and $10 \%$ at high level of watershed. Therefore, to reduce sedimentation problem and ensue sustainability of the watershed need to special attention for implementing recommended SWC intervention at the earlier (Figure 11).

\section{Classification and prioritization of critical erosion prone area for conservation planning}

Mapping of erosion hazard risk is useful for rapidly identifying and pre-selecting areas that needs to be given priority in SWC works and/or for the watershed management planning. For purposes of prioritization this exercise out puts should be used combined with soil erosion assessment discussed in previous sections of this report. Regarding delineation of micro watersheds as erosion prone areas according to the severity level of soil loss, priority is given for a targeted and cost-effective conservation planning..$^{18}$ According to LUPRD study; FAO 1984, the soil loss of watershed is classified in to four main classes as provided in table below. None to Slight rates of soil erosion ( $(0-10 \mathrm{t} / \mathrm{ha})$ is cover the almost $66 \%$ of watershed moderate about $23 \%$ and high about $10 \%$ of erosion rate as seen from the erosion rate distribution map as well as the table above. The upstream of catchment needs management \& protection of those existing resources and the fundamental attention for SWC as recommended bases. Several studies shows that from the relationship between the slope of the watershed and the erosion rate, the higher the slope, the higher the erosion risk (Hoyos, 2005). The main causes of high soil erosion on steeper bank of the watershed area could be due to inappropriate land management practices like deforestation, cultivation of marginal land, intensive cultivation, and poor vegetation during critical rainfall period. In my study area watershed slope classes, the largest soil loss rate could be mainly due to high erosivity ( $R_{-}$factor) value from heavy rainfall, erodibility ( $\mathrm{K}$ factor), Table 8 high $\mathrm{LS}$ value especially slope steepness, soils without support practice factors. Field observation report depicted that, the steeper parts of the land slope lack vegetative cover coupled with intensive tillage operation, inadequate soil and water conservation measures; also, ignorance of land users to periodically maintain structures such as removing sediment from the channel and repairing the embankment was the major problems identified and resulted to high soil loss potential in this area. 


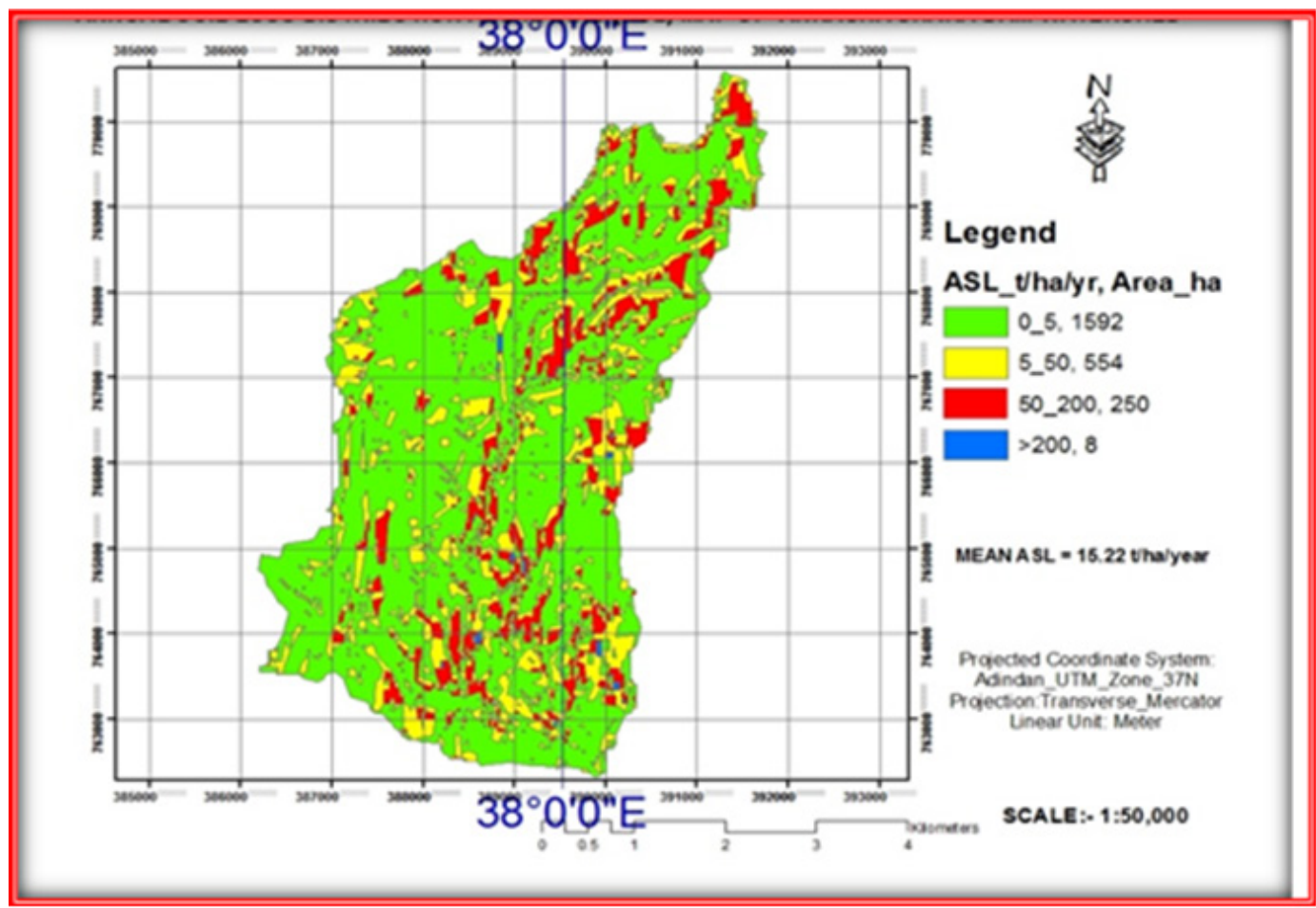

Figure I I Annual soil loss rate, extent and distribution map of Anka-shashsara Watershed.

Table 8 Soil loss rate of the watershed

\begin{tabular}{lllll}
\hline No & Soil loss class & Soil Loss (t/ha/yr) & Area (ha) & Coverage (\%) \\
\hline I & None -Slight & $0-5$ & 1592 & 66.22 \\
2 & Moderate & May-50 & 554 & 23.04 \\
3 & High & $50-200$ & 250 & 10.4 \\
4 & Severe & $>200-255$ & 8 & 0.33 \\
\hline
\end{tabular}

\section{Watershed development and management strategies}

Since watersheds are shaped by complex ecological relationships and diverse social systems that are continually responding to dynamic economic, social and cultural forces, watershed planning must first and foremost be an interdisciplinary process. It will require technical expertise in geology, hydrology, biology, ecology, engineering, environmental science, resource management, social science and rural development planning. It must also strive to relate these processes to the human factor. It should address linkages between land use and water management, upland watershed issues and downstream concerns, public values and economic natural resource use, community well-being and sustainable watersheds, short term activities and long term sustainability issue. Consideration of these issues requires participation not only by different agencies but also by farmers, businesses, environmental groups, and technical specialists from the profit and non-profit sectors, disadvantaged communities and the public as a whole. ${ }^{19-25}$ Having in mind all these factors, the anticipated integrated watershed management plan will consider the following bench mark issues:

Recognize and address multiple perspectives, issues, and objectives, including local, regional, and federal concerns of environmental, economic, and social nature.
I. Integrate and coordinate planning, management, monitoring, and community activities across agencies, and nongovernmental entities.

II. Provide for inclusive and participatory involvement by all agencies and all stakeholders to ensure meaningful input, including disadvantaged or hard to reach communities and stakeholders.

III. Use or provide at least a minimum level of assessment early in the process to provide a scientific foundation for moving forward.

IV. Allow for a long-term, phased implementation strategy while managing for shorter term project delivery.

V. Develop a monitoring strategy for projects to provide scientifically valid information about effectiveness and to determine if overall plan is meeting stated objectives.

VI. Establish a process for ongoing, informed decision-making through adaptive planning, management and monitoring. ${ }^{26,27}$

A watershed plan does not need to offer all the answers. Instead, it can lay out a long-term process towards finding answers and improving solutions and a long-term system of acquiring new 
information on key issues and trends to modify the management program. Moreover, watershed as a complex dynamic system will require time, information, and resources to manage. Hence, the study report suggests to follow the program approach of watershed plan and management, in short term the study identified major programs that could give instant effect to the rehabilitation endeavor and that would pave the way to future sustainable management of the watershed. In order to ease implementation of the watershed development plan; the watershed need to be divided into smaller sub-watersheds. Each subwatershed as a hydrological unit is connected, and any modification of the land use in watershed or sub-watershed will reflect on the water as well as sediment yield of the overall watershed. Accordingly, the Anka-shashara watershed is classified in to micro-watershed/subwatershed, according to the Ethiopian Soil and Water Conservation manual the minimum area to be treated as micro watershed is about 500 hectare of land, off course it depends on particular site condition and type. ${ }^{28-33}$

\section{Conclusion and recommendations}

Soil erosion is identified as one of the growing land management problem resulting in both on-site and off-site effects. It is growing and more expanding problem in the watershed, where rainfall is more intense and soils are highly erodible due to the relatively erodible top soil and low structural stability. In line with this, the watershed is under gradual clearing of the existing forest resources, which is directly affecting and exposing the soil resource of the watershed to erosion. ${ }^{34}$ Those practices reduce the protective plant cover, thereby exposing the soil surface to the destructive impact of high-intensity rainfall. Considering the mounting problem of soil erosion and its impacts, it is necessary that appropriate management measures be undertaken. To achieve this, a sound knowledge of spatial variations in soil erosion is necessary. ${ }^{35}$ Because of the high cost of conservation and the competing production objectives such as population increase, infrastructure development, and land degradation, there is a need to target responses and resources to areas of high risk rather than spreading them equally across the landscape. Different land management program can then be implemented to deal with the various land degradation problems. These attempts must take into consideration the biophysical and socioeconomic conditions of the Watershed sites. Therefore, this study report has placed the following key recommendations:

I. Capacity building: Increasing attitude of the watershed community towards sustainable development/Integrated Watershed Management (IWM) through effective and consistent trainings. This includes skill trainings of Woreda agricultural experts \& Kebele DA's in effective adoption of IWM,

II. Designing energy efficient home systems: supplying household cook stoves, infrastructure such as roads, developing social services, attainable credit conditions and technology.

III. Because of accelerated land degradation, there must be sustainable soil conservation strategies in the area

IV. The vegetation cover of the land should be improved to reduce the removal of soil organic matter

V. The water-holding capacity and nutrient availability of the soil should be increased by applying biological and agronomic conservation schemes to increase agricultural productivity and minimize biodiversity loss in the area
VI. The farmers should be included in all such schemes as active participants. ${ }^{36-41}$

\section{Acknowledgments}

None.

\section{Conflicts of interest}

The authors have not declared any conflict of interests.

\section{References}

1. Asmamaw LB, AA Mohammed, TD Lulseged. Land use/cover dynamics and their effects in the Gerado catchment, north-eastern Ethiopia International Journal of Environmental Studies. 2011;68(6):883-900.

2. World Bank. Watershed management approaches, policies, and operations: lessons for scaling up. The World Bank group, washington, dc. 2008 .

3. Anteneh B, Tesfaye A, Tessema Z. Woody species diversity, population structure, and regeneration status in the Gra-Kahsu natural vegetation, southern Tigray of Ethiopia. $J$ of Elsevier. 2019;5(1):e01120.

4. Warra HH, Assen MA, Melanie DN. Impact of land cover changes and topography on soil quality in the Kasso catchment, Bale Mountains of southeastern Ethiopia. Singapore Journal of Tropical Geography. 2015;36 (2015) 357-375.

5. Mekuria A. Forest conversion-soil degradation-farmers'perception nexus implications for sustainable land use in the southwest of Ethiopia. In: Vlek P et al., editors. Ecology and development series no. 2005;26:161.

6. Emrah, HE, Günay E, İlhami B. Use of USLE/GIS Methodology for Predicting Soil Loss in a Semiarid Agricultural Watershed. 2007;131(13):153-161

7. Kruger HJ, Berhanu F, Yohannes GM, et al. Inventory of indigenous soil and water conservation measures on selected sites in the Ethiopian Highlands. 1995. p. 34.

8. FAO, (Food and Agriculture Organization) and UNEP. Provisional Methodology for Assessment and Mapping of desertification. FAO, Rome, Italy. 1984.

9. Hurni H, Herweg K, Portner B, et al. Soil Erosion and Conservation in Global Agriculture. In Land Use and Soil Resources. Springer, Dordrecht 2008. p. $41-71$

10. Sertu S. Degraded soil of Ethiopia and their management. In: FAO/ISCW expert consultation on management of degraded soils in Southern and East Africa. $2^{\text {nd }}$ network meeting, 18-22 September, Pretoria. 2000.

11. Sonneveld, BGJS. Land Under Pressure: The Impact of Water Erosion on Food Production in Ethiopia. Shaker Publishing, Maastricht, the Netherlands. 2002.

12. Sonneveld BGJS, MA Keyzer, PJ Albersen. A non-parametric Analysis of Qualitative and Quantitative Data for Erosion Modeling: A case Study for Ethiopia. Conference of ISCO, Lafayette, US. 1999. p. 24-28.

13. Cerda A, Doerr SH. The effect of ash and needle cover on surface runoff and erosion in the immediate post-fire period. Catena. 2008;74:256-263.

14. Ebrahim E, Mohammed A, Asmamaw L. Implications of land use/cover dynamics on soil erosion potential of agricultural watershed, northwestern highlands of Ethiopia. Environmental systems research.2018;21:7-21.

15. Hellden U. An Assessment of Woody Biomass, Community Forests, Land Use and Soil Erosion in Ethiopia. Lund University Press, Lund. 1987.

16. Hurni H. Soil Conservation Manual for Ethiopia. Ministry of Agriculture: Addis Ababa. 1985a. 
17. Hurni H. Guidelines for Development Agents on Soil Conservation in Ethiopia. Community Forest and Soil Conservation Development Department, Switzerland. 1986.

18. Kaltenrieder J. Adaptation and Validation of the Universal Soil Loss Equation (USLE) for the Ethiopian-Eritrean Highlands. MSc Thesis, University of Berne, graphisches Institute. 2007.

19. Arc View. [GIS software]. Version 10.3. Help Files: Flow Direction Description and Flow Accumulation Description.

20. Belay T. Famers perception of erosion hazard and attitude towards soil conservation in gununo wolaiata, southern Ethiopia. Ethiopian journal of development research. 1992;14(2).

21. Buol SW, Hole FD, McCracken R, et al. Soil Genesis and Classification. Fourth Edition, Iowa State University Press, Ames, IA 50014. 1997. p. 527.

22. FAO, (Food and Agriculture Organization of the United Nations). Forest Resources Assessment 1990 - global synthesis. FAO Forestry Paper No. 124. Rome. 1995a.

23. FAO, (Food and Agriculture Organization of the United Nations). State of the World's Forests. 1997.

24. FAO, (Food and Agriculture Organization of the United Nations. Reconnaissance of land evaluation in Ethiopia. Addis Ababa, Ethiopia. 1989.

25. FAO, (Food and Agriculture Organization). Ethiopian Highland reclamation Study (EHRS). Final Report, Vol: 1 and 2, Rome. 1984.

26. FAO, (Food and Agriculture Organization). Ethiopian Highland Reclamation Study: Report prepared for the government of Ethiopia by FAo, Rome. Vol.I 1986.

27. Federal Democratic Republic of Ethiopia Rural Land Administration and Land Use Proclamation, 2005. Proclamation No. 456/2005, Addis Ababa Ethiopia. 2005.

28. Hoyos N. Spatial modeling of soil erosion potential in a tropical watershed of the Colombian Andes. Catena. 2005;63(1):85-108.

29. Hudson N. Soil Conservation, $3^{\text {rd }}$ edn. Batsford: London, 1997. p. 391.
30. Hurni H. Erosion-productivity-conservation systems in Ethiopia. Paper Presented at the $4^{\text {th }}$ International Conference on Soil Conservation, 3-9 November 1985, Maracay, Venezuela. 1985b.

31. Hurni H. Land degradation, famine, and land resource scenarios in Ethiopia. Pimentel D (Ed.) 1993. p. 27-62.

32. Meseret M, Dawit D. Evaluation of Soil and Water Conservation Measures on Physico-Chemical Properties of two Watershed in Humbo Woreda, Southern Ethiopia. International Journal of Novel Research in Life Sciences. 2019.

33. Mesfn A, Mohammed A. Effects of land cover changes and slope gradient on soil quality in the Gumara watershed, Lake Tana basin of North-West Ethiopia. Modeling Earth Systems and Environment. 2019.

34. MoARD (ministry of agriculture and rural development). Guideline for community based participatory watershed development and management. Addis Ababa Ethiopia. 2005.

35. Mohammed A, Belay T. Characteristics and classification of the soils of the plateau of simen mountains national park (smnp), Ethiopia. Sinet Ethiop J Sci. 2008;31(2):89-102.

36. Morgan RPC. Soil Erosion and Conservation. Longman Scientific and Technical Group Ltd: Hongkong; 1986;111-210.

37. SCRP, (soil conservation research projects). Degradation and conservation of the resources in the Ethiopian highlands. Mountain research and development. Switzerland. 1987;8(2/3).

38. Teshome A, de Graaff J, Stroosnijder L. Evaluation of soil and water conservation practices in the north-western Ethiopian highlands using multi-criteria analysis. Front Environ Sci. 2014;2:60.

39. US EPA, (United States Enivornmental Protection Authority). Watershed Approach framework. Carol M. Browner, Administrator. 1996.

40. Wischmeier WH, DD Smith. Predicting rainfall erosion losses: A guide to conservation planning USDA, Agricultural handbook. 537. U.S Government printing office. 1978 .

41. Wubie MA, Assen M, Nicolau M. Patterns, causes and consequences of land use/cover dynamics in the Gumara watershed of Lake Tana basin, Northwestern Ethiopia. J of springer. 2016. 